\title{
Chapter 16 \\ Nature-Based Solutions and Protected Areas to Improve Urban Biodiversity and Health
}

\author{
Kathy MacKinnon, Chantal van Ham, Kate Reilly, and Jo Hopkins
}

\begin{abstract}
Biodiversity and healthy natural ecosystems, including protected areas in and around cities, provide ecosystem benefits and services that support human health, including reducing flood risk, filtering air pollutants, and providing a reliable supply of clean drinking water. These services help to reduce the incidence of infectious diseases and respiratory disorders, and assist with adaptation to climate change. Access to nature offers many other direct health benefits, including opportunities for physical activity, reduction of developmental disorders and improved mental health. Economic valuations of green spaces in several cities globally have found that nature provides billions of dollars in cost savings for health services. Protected areas are increasingly common in, and around, cities to protect biodiversity and ecosystem services, including these benefits for health. Many cities are also launching programmes to enhance the health and environmental benefits of parks, based on a model of Healthy Parks, Healthy People, by Parks Victoria in Australia. Partnerships between conservationists, city planners and health authorities are critical to maximise these benefits. In some places, medical professionals prescribe time in nature, and some cities specify standards for urban green spaces to enhance their health benefits. The United Nations Sustainable Development Goals provide an important global framework for such partnerships from global to local level.
\end{abstract}

Keywords Health $\cdot$ Protected areas · Nature $\cdot$ Urban · Climate change

\footnotetext{
K. MacKinnon ( $\square)$

IUCN World Commission on Protected Areas, Gland, Switzerland

e-mail: kathy.s.mackinnon@gmail.com

C. van Ham · K. Reilly

IUCN European Regional Office, Brussels, Belgium

e-mail: chantal.vanham@iucn.org; kate.reilly@iucn.org

J. Hopkins

Parks Victoria, Melbourne, Australia

e-mail: jo.hopkins@parks.vic.gov.au
} 


\section{Highlights}

- Protected natural areas in, and adjacent to, cities provide ecosystem benefits and services that support human health and climate change adaptation.

- Urban green spaces provide billions of dollars in cost savings for health services.

- Partnerships between conservationists, city planners and health authorities are critical for the continued protection of protected nature areas in and around cities.

\subsection{Introduction}

Biodiversity and healthy natural ecosystems underpin and sustain human livelihoods and well-being by providing essential services such as food, clean air and water, and protection against floods, coastal storms and other natural disasters (Dudley et al. 2010). These functions will become ever more important in helping people to cope with, and adapt to, climate change and its impacts. Water scarcity, food security and biodiversity loss will be some of the greatest global challenges over the next few decades; all will be exacerbated by climate change and have consequences for human health and well-being. In Africa alone some 75 million-250 million people are expected to be experiencing water shortages by 2020 , with a $50 \%$ reduction in yields from rain-fed agriculture, leading to more food shortages, poverty, insecurity and migration (World Bank 2010). In Asia, climate change is projected to lead to decreased freshwater availability and the increased prevalence of water-borne diseases, whereas coastal areas, especially the densely populated delta regions, will be exposed to a greater risk of flooding. These climateinduced changes will have a cost in terms of human health, with more endemic morbidity and mortality due to the rise of diarrhoea and other water-borne diseases and the spread of certain disease vectors (World Bank 2010; Müller et al. Chap. 4, this volume).

Land degradation and the continued erosion of the natural capital that underpins functioning ecosystems - including soil, water and biodiversity - are an increasing threat to human health and sustainable livelihoods. The World Health Organisation (WHO) suggests that up to a quarter of all deaths globally could be avoided simply by improved management of environmental issues such as air pollution, water contamination and dust from degraded drylands (WHO 2005).

Over half of the world's population now lives in cities, and it is predicted that nearly $70 \%$ of people will be living in urban environments by 2050 (United Nations 2014). In the coming decades, $95 \%$ of urban expansion is expected to occur in the developing world, including in some of the countries most likely to be impacted by climate change and more erratic weather patterns (United Nations 2014). Cities are not urban 'islands'; they depend on surrounding natural landscapes and seascapes, including protected areas, to provide critical ecosystem services, such as food, clean 
air, water supplies and protection against floods, coastal storms and other natural disasters (Dudley et al. 2010; Gómez-Baggethun et al. 2013). At the same time, rapid urbanisation is affecting the very ecosystems on which cities and urban citizens depend by exerting pressures on freshwater supplies and increasing pollution (Mcdonald et al. 2008). With the dual challenges of climate change and rapid urbanisation, improving the public health of urban residents will be of particular importance.

Increasing urbanisation brings its own challenges in terms of human health. Non-communicable diseases such as diabetes, cardiovascular disease, cancer and depression are now among the fastest growing health challenges around the world (WHO 2005, 2014). While many factors are involved in this increase, lifestyle factors such as physical activity, diet and stress are particularly important (WHO 2014). There is also increasing evidence that lack of access to nature in cities, and associated sedentary, indoor lifestyles, is linked with physical and mental health disorders including vitamin D deficiency, asthma, anxiety and depression (Gelsthorpe 2017). Better access to nature has been shown to have positive physical and mental health benefits and can even contribute to healing after surgery (Sandifer et al. 2015; Townsend et al. 2015, Cook et al. Chap. 11, this volume).

There is increasing evidence that biodiversity and healthy natural ecosystems, including protected areas, can help climate change adaptation by serving as a natural buffer against climate-related disasters, contributing to water and food security, and playing a critical role in maintaining human health and well-being (Dudley et al. 2010; IUCN 2016a, b; Gómez-Baggethun et al. 2013). A healthy ecosystem is one that is sustainable - that is, it has the ability to maintain its structure (organisation) and function (vigour) over time in the face of external stress (resilience) (Costanza et al. 1999). In this chapter, we argue that effective protection, management and restoration of protected areas and other natural ecosystems can be practical, cost-effective and help to meet the interlinked goals for biodiversity, health and climate change adaptation in a rapidly-urbanising world. Identifying and understanding the synergies between nature, health, urban development and national climate change policies and programmes will be critical for delivering many of the United Nations Sustainable Development Goals (SDGs), especially those relating to water, health and sustainable cities.

\subsection{Protected Areas: Contributing to Healthy Societies}

Protected areas and other natural ecosystems can contribute positively to human health in various ways, many of which are just beginning to be understood. These can be categorised as follows: (i) by providing ecosystem benefits and services that sustain life and regulate against detrimental health effects from climate, floods, infectious diseases, etc.; (ii) as botanical sources for both traditional and modern medicines; and (iii) by providing direct benefits to physical, spiritual and mental health through time spent in nature. 


\subsubsection{Ecosystem Benefits and Services}

Protected areas and other natural ecosystems, such as wetlands and forested areas, including those within and adjacent to cities, can provide positive health benefits and services (Dudley et al. 2010; Townsend et al. 2015). Conserving or restoring forests can, for example, reduce the risk of malaria and certain other diseases. Watersheds retaining natural vegetation, particularly forests, provide cleaner water than more degraded watersheds. Protected areas can maintain dryland vegetation, stabilising soil, preventing desertification and dust storms, and reducing the suspended solids in air that create major respiratory problems (WCPA 2015). Marine protected areas and healthy wetlands boost fish stocks, contributing to food security and adequate protein for coastal and subsistence communities (Halpern 2003).

Access to clean water is an essential pre-requisite for public health, and especially important in densely populated cities. Poor planning, inefficient use, population growth and increasing demands for water all mean that the provision of adequate, safe supplies of water remains a major source of concern. One in five people in the developing world live without a reliable water supply and two billion city dwellers do not have adequate sanitation. Lack of clean water increases infant mortality and the prevalence of water-borne diseases, reducing productivity, straining health services, and causing millions of deaths every year (WHO 2005; Stolton and Dudley 2010; WCPA 2015). Furthermore, water shortages undermine agricultural productivity and food security, while excess water, as a result of storms and floods, creates not just immediate social and economic impacts but is often followed by disease and epidemics (Dudley et al. 2010). Protection of natural habitats helps regulate against flooding and other weather-related events and sustains the availability of high-quality water for health, social and economic development.

Functioning natural ecosystems within well-managed watersheds and protected areas provide efficient and cost-effective ways of supplying clean water (see Box 16.1). One-third of the world's largest 100 cities, including Jakarta, Dar es Salaam, New York, Melbourne and Sydney, rely on forest-protected areas for a substantial part of their domestic water supply (Dudley and Stolton 2003). High-altitude, tropical montane vegetation provides clean water supplies to major cities in Latin America. Protected areas in Colombia, for example, cover about $10 \%$ of the country and provide $50 \%$ of Colombians with water. In the capital, Bogotá, eight million people get $80 \%$ of their water from the paramos vegetation protected in the Chingaza National Park (WCPA 2012). Recognising the importance of this natural function, the mayors of the surrounding municipalities are supporting restoration of natural habitats within the Park.

Protected wetlands can also provide critically important water supplies and protection from flooding for many urban populations. The 89,000 hectare Lagoas de Cufada Natural Park in southern Guinea-Bissau was created to protect the largest freshwater reserve of the country. In a region where rainfall has been reducing, this Ramsar site plays a crucial role in supplying water for the city of Buba, as well as 


\section{Box 16.1: Protected Areas Providing Clean Water for Domestic Use}

In many parts of the world adequate supplies of potable water depend on protected areas:

- Kerinci Seblat National Park in Indonesia protects the head waters of two of Sumatra's major rivers, the Musi and the Batanghari, which provide downstream water supplies for major cities such as Jambi, Padang and Palembang, as well as millions of hectares of irrigated farmlands.

- In Ecuador, about $80 \%$ of Quito's 1.5 million residents receive drinking water from two protected areas in the Andes.

- The 22,000 hectare Te Papanui Conservation Park, in New Zealand's Lammermoor Range, provides the Otago region with essential water flows valued at NZ\$ 93 million for urban water supply.

- Protected areas are particularly valuable in water resource terms where they occur upstream of large population centres in dry environments. The Cholistan Wildlife Sanctuary upstream of Karachi, Pakistan (population 18 million), for example, provides water services estimated at US\$ 100 million per year to the downstream population.

- Six reservoirs in the Catskills Mountains provide water to nine million people in the New York City area. Careful management of the landscape and protected areas provide good quality water through the largest unfiltered water supply in the USA, with a few million dollars spent on watershed protection saving billions of dollars in infrastructure costs for filtration.

Sources: Dudley et al. 2010; World Bank 2010.

contributing to local livelihoods and the survival of hundreds of plant and animal species (Dudley et al. 2010).

Elsewhere, natural ecosystems, including wetlands and grasslands, play a key role in reducing pollution levels and particulate matter in water, as well as absorbing storm-water run-off. Wetlands can reduce high levels of nutrients, and some water plants concentrate toxic materials in their tissues, thus purifying surrounding water. For example, Florida's cypress swamps remove $98 \%$ of all nitrogen and $97 \%$ of all phosphorus from wastewater entering the wetlands. Natural wetlands also help dilute contaminants derived from upstream agriculture, thus ameliorating water quality in agriculturally-dominated landscapes in the world's major river basins (Dudley and Stolton 2003).

However, maintaining healthy ecosystems to provide these environmental benefits, such as adequate water supplies for agriculture and domestic use, will become an increasingly challenging issue with climate change, habitat degradation and biodiversity loss, especially in the developing world (Dudley et al. 2010; WCPA 2011). In South Africa, for instance, invasive alien species are estimated to affect ten mil- 
lion hectares (more than $8 \%$ of the land area) with significant ecological and economic costs. With high evapotranspiration rates, invasive alien trees are an immense burden to already water-scarce regions and reduce the amount of water available to reservoirs, industry and downstream agriculture. Large-scale programmes to remove these species are being undertaken in many of South Africa's watersheds, providing benefits to biodiversity, water supplies and employment opportunities for poor and disenfranchised communities under the Working for Water Programme (World Bank 2010).

The multiple roles of protected areas will become more valuable as climatic events become more severe, helping to reduce the impact of natural hazards and disasters and buffering vulnerable communities against all but the most severe flood and tidal events, landslides and storms (Stolton et al. 2008). Intact mangroves provide protection and reduce the damage caused by tsunamis and hurricanes, while also harbouring vital fish nurseries. In Sri Lanka, the Muthurajawella marsh near Colombo affords flood protection valued at over US $\$ 5$ million/year (Costanza et al. 2008). In some cases, investments in protecting and restoring natural habitats may be more cost-effective for reducing disaster risk than investing in hard infrastructure alone. In Vietnam, where local communities have been planting and protecting mangrove forests as a buffer against storms, an initial investment of $\$ 1.1$ million has saved an estimated $\$ 7.3$ million a year in sea dyke maintenance and significantly reduced the loss of life and property from Typhoon Wukong in 2000 in comparison with other areas (IFRC 2002).

Although the value of ecosystem services in terms of water regulation and supply of clean water alone has been estimated at US $\$ 2.3$ trillion globally (Costanza et al. 1997), very little of this potential value is spent on ensuring that these ecosystem functions are sustained. Many protected area systems are inadequately funded (Watson et al. 2014). One promising trend is the implementation of payment for ecosystem services (PES) schemes to compensate protected areas, upstream communities, indigenous peoples and private landowners for maintaining forests and other water-regulating habitats, such as those being piloted in Colombia, Ecuador, Mexico and Nicaragua (WCPA 2012).

\subsubsection{Local and Global Medicines}

Natural ecosystems are an important source of local, traditional and global medicines. Indeed, more species of medicinal plants are harvested than of any other natural product, and many rural and urban communities, especially in the developing world, rely on medicinal plants for primary health-care (Stolton and Dudley 2010). The economic value of medicinal plants and their extracts and drug derivatives has been estimated in billions of dollars (Ahn 2017). Today many of these plants are conserved only in protected areas; indeed, some protected areas have been specifically established to protect plants used in traditional medicines. A good example is 
the Alto Orito Indi-Ande Medicinal Plants Sanctuary in Colombia proposed by the indigenous Kofán communities (Stolton and Dudley 2010).

The value of protected areas to provide primary and affordable health-care products is a global phenomenon. Medical drugs derived from natural products support a huge pharmaceutical industry; over half of today's synthetic medicines originate from natural species, including drugs like aspirin, digitalis and quinine. Bioprospecting in protected areas has already turned up compounds that are being used, or are in the process of development, for combatting high blood pressure, cancer, leukaemia, HIV, enlarged prostate and malaria, and for antibacterial and antifungal treatments. Protected areas are important sources of herbs and medicinal plants that provide important health-care, social, cultural and livelihood benefits to local people (Stolton and Dudley 2010).

\subsubsection{Provision of Direct Health Benefits}

There is growing evidence that access to protected areas, ecological reserves, wetlands and forest areas and other natural spaces sustains a variety of physical, psychological and social benefits and enhances the health and well-being of people across their lifespan (Sandifer et al. 2015; Townsend et al. 2015). In Australia, Parks Victoria's Healthy Parks Healthy People (HPHP) programme recognises that parks are fundamental to vibrant and healthy communities, fostering social connections that are vital to community cohesion and contribute to social well-being (Townsend et al. 2015). Recreation and time spent in protected areas can be linked to physical and mental health benefits among adults, including the elderly, while research has shown that parks foster active play in children and improve mental and social health of adolescents during what is often a challenging time of life (Townsend et al. 2015).

Several countries have now adopted HPHP programmes in their national parks and protected areas, including national parks in the USA, Colombia, Finland and New Zealand. Many studies find that access to protected areas and other green and blue spaces increases levels of physical activity and consequently physical and mental health, although the relationship varies between type of activity and population group, and is affected by other factors such as perceived safety and distance to amenities (Hartig et al. 2014). In India, for example, Keoladeo National Park provides free access to a designated $2-\mathrm{km}$ stretch that up to a thousand 'morning walkers' enjoy every day between 5 a.m. and 7 a.m. Similarly, in the UK, many protected areas actively promote outdoor activity programmes, such as the 'Green Gym' scheme (Trust for Conservation Volunteers 2016) and the Walking for Health programme (Marselle et al. 2014), which use the natural environment as a health resource. In Japan, Shinrin-yoku is the traditional practice of taking in the atmosphere and energy of the forest to improve health and reduce stress (Dudley et al. 2010). Building on the therapeutic effects of nature, the Victoria HPHP programme has developed long-term cooperation with mental health facilities to bring patients into parks and protected areas. This increased physical activity and access to green 
space has clear benefits for physical health, while nature can reduce feelings of anger, sadness and anxiety (Hartig et al. 2014).

A growing body of evidence is also demonstrating that the sense of connectedness with nature that results from positive nature-based experiences, whether in a city, a national park, or another natural ecosystem, leads to the development of positive attitudes and behaviours towards nature and its protection (Wright and Matthews 2014; Teisl and O'Brien 2003). Policies and programmes that create opportunities for greater access to nature thus have the added benefit of building public support for biodiversity conservation and political will for the protection of intact natural ecosystems that underpin human health and well-being (for more information, see Davies et al. Chap. 12, this volume).

\subsection{Nature and Health in an Urban Setting}

Many of the benefits that derive from protected areas in the broader landscape also apply to natural spaces in urban settings. Urbanisation both intensifies biodiversity loss and presents its own unique health and lifestyle challenges and opportunities. Cities are dependent on surrounding natural landscapes and protected areas to provide critical ecosystem services, but parks, waterways and river corridors can provide links and 'stepping stones' from cities to the broader landscape. Maintaining natural habitats and green and blue spaces within cities can also provide ecosystem services that are important for climate change adaptation.

Urban parks, green spaces and wetlands absorb rainwater and stormwater run-off and alleviate air pollution. The roles and benefits of natural ecosystems as green infrastructure will become more important with climate change (Beatley 2014). Tree cover in urban settings has been shown to reduce rainwater run-off and reduce flood risk. A study of street trees in Manchester, UK, found that surface runoff was up to $62 \%$ lower in asphalt plots with a tree planted in the middle compared to asphalt plots with no trees. Grass plots almost completely prevented surface runoff, and therefore reduced flood risk (Armson et al. 2013; Lindley et al. Chap. 2, this volume). Similarly, urban green spaces can help reduce air pollution. More than three million people globally die each year from outdoor air pollution (WHO 2016). A study by the University of Exeter's medical school into the impact of urban greenery on asthma suggests that respiratory health can be improved by the expansion of tree cover in very polluted urban neighbourhoods (Alcock et al. 2017). In the UK, over 5.4 million people receive treatment for asthma, with an annual cost to the National Health Service of around £1 billion; asthma is estimated to lead to over 1,000 deaths a year. The findings of these studies provide strong evidence for promoting the role of trees in urban planning and public health policy.

Increasing urbanisation and changing lifestyles have resulted in more people spending less time in nature, doing less physical activity, and experiencing greater stress, and negative health outcomes such as greater obesity and physical and men- 


\section{Box 16.2: Addressing the Nature-Deficit Disorder}

Richard Louv (2005) coined the term 'nature-deficit disorder' to describe the range of behavioural problems, such as diminished use of the senses, attention difficulties, and higher rates of physical and emotional illnesses, that result from less time spent outdoors. Protected areas, urban parks and other green spaces are crucial gateways for connecting people with nature (IUCN, Canadian Parks Council 2017; IUCN 2014). Although towns and cities may have considerably lower species densities than surrounding rural areas, urban settings can be important for biodiversity conservation and provide natural environments that can contribute to human health and well-being in many ways (IUCN 2014). For example, the Golden Gates National Recreational Area in San Francisco, California, USA, is important for both nature and health. It contains a range of marine, coastal and terrestrial habitats that support 1,300 animal and plant species, including 36 threatened species. It also includes an area of ancient redwood forest protected as a national monument. An institute of the non-profit cooperating association of the recreational area uses the park to pilot-test new ideas for using parks as solutions to wider social challenges. One of its projects aims to promote healthy and sustainable food choices in the park and to use the National Park Service's purchasing power to influence the food supply chain to address obesity, type 2 diabetes and other health issues (IUCN 2014).

tal health problems (see Box 16.2). Access to nature in urban environments can also provide benefits for physical and mental health and contribute to children's cognitive, physical and social development (Russell et al. 2013). Similarly, a recent study in New Zealand found that risk of cardiovascular disease was lower in neighbourhoods with more than $15 \%$ green space than those without (Richardson et al. 2013). Natural spaces present a cost-effective, high-return investment that provide direct benefits for public health and education, improve living conditions, and build resilience to climate and environmental change.

Several major cities now have protected and conserved areas and even national parks within or directly adjacent to the metropolitan areas (IUCN 2014). These range from small wetland areas managed by an NGO in central London and urban protected areas in central Sydney and Rio de Janeiro to the much larger Table Mountain National Park, which covers some 25,000 hectares in the centre of Cape Town, South Africa, which protects key habitats and Cape flora in the world's smallest floral kingdom. These parks come under a range of governance types from NGOs to park agencies and municipal authorities, including co-management arrangements (IUCN 2014). They provide a range of services including conservation, recreation, tourism, health benefits and water resource management, as well as providing opportunities for visitors to learn about biodiversity conservation and the impacts of climate change (see Box 16.3). 
Box 16.3: ClimateWatch Trails for Schools and Communities (Australia) ClimateWatch is a national citizen science programme designed to enable every Australian to be involved in collecting and recording data that helps shape the country's scientific response to climate change.

Parks and protected areas provide ideal locations in which to assess the impacts of climate change as they provide scientists with information on landscapes in contrast with developed and urban areas. ClimateWatch trails are a great opportunity for park visitors to engage in long-term climate change research by recording their observations of nature.

Parks Victoria is partnering with Earthwatch Australia to develop new ClimateWatch trails in parks. The programme is aimed at schools and community groups in areas of social disadvantage from regional Victoria, encouraging students and community members to get active in the outdoors by recording data that can be used by scientists to monitor the natural environment. School-based curriculum resources have been developed as part of this programme.

The programme connects education, inclusion and citizen science, along with the numerous health and well-being benefits of connecting people from all walks of life to parks.

Source: Parks Victoria.

Urban parks and other forms of natural infrastructure can conserve healthy ecosystems and improve human health and well-being, while addressing challenges related to climate change, such as heat stress, storm surges and flooding (IUCN 2014). Maintaining and expanding both terrestrial and aquatic natural spaces must therefore be a key consideration in urban planning if the health of residents is a priority. Since cities also depend on and affect their surroundings, planners should also consider connections between cities and the broader landscapes in order to ensure that impacts on natural ecosystems are minimised and positive contributions to biodiversity conservation are maximised (see also Heiland et al. Chap. 19, this volume). This is challenging to do effectively and equitably, given the conflicting demands for land, resources and development, particularly in developing and rapidly urbanising parts of the world. Therefore, it is important that biodiversity conservation is recognised as a valuable contribution to a range of policy objectives, such as job opportunities, youth and community development, public health, water, energy and adaptation to climate change.

Recommendations from the IUCN World Parks Congress in Sydney in 2014 (IUCN 2014) and the New Urban Agenda (United Nations 2016), agreed at Habitat III in Quito in 2016, recognise the relevance of protected areas and nature to sustainable cities. Other global policy processes have also explicitly made the connection between nature and health. The UNFCCC Paris Agreement recognised and promoted the valuable role of ecosystem-based adaptation, including protected areas, to address climate change impacts (United Nations 2015). The Convention on 
Biological Diversity (CBD) COP13 Cancun Declaration on Mainstreaming the Conservation and Sustainable Use of Biodiversity for Well-being indicates that the Parties commit to "promote the conservation, sustainable use, and where necessary, restoration of ecosystems as a basis for achieving good health" (CBD COP13, 2016). At the IUCN World Conservation Congress in Hawai'i a resolution was adopted (IUCN WCC-2016-Res-064-EN) to strengthen cross-sector partnerships to recognise the contributions of nature to health, well-being and quality of life. See Korn et al. Chap. 14, this volume, for more detail on the policy support for biodiversity, health and climate change.

One way to increase health benefits is to incorporate nature-based solutions in urban policy through targets for the provision of parks and green spaces within a certain distance of people's homes (Shanahan et al. 2015). For example, East Dunbartonshire Council in Scotland sets out standards for the quantity, quality and accessibility of open space, including parks, gardens, play areas and nature reserves, for its population (East Dunbartonshire Council 2015). It is interesting to note that, along with other commitments to biodiversity conservation and environmental protection, the UK's new 25-Year Plan for the Environment includes the following commitment: "Making sure that there are high quality, accessible, natural spaces close to where people live and work, particularly in urban areas, and encouraging more people to spend time in them to benefit their health and well-being" (Her Majesty's Government 2018). Integrated policy and programmes that recognise the increasingly important contribution of nature and parks for our physical, mental, cultural and spiritual health and well-being are essential (see Box 16.4).

The close links between biodiversity conservation and health are also recognised in the Victorian public health and well-being plan 2015-19 and Victoria's new biodiversity plan (State of Victoria Department of Environment, Land, Water and Planning 2017). The biodiversity plan was launched in 2017 at the 15th World Congress on Public Health in Melbourne accompanied by a joint ministerial statement, the Victorian Memorandum for Health and Nature (D'Ambrosio and Hennessy 2017). The memorandum provides direction for the Victorian Government's health and environment portfolios to collaborate in order to maximise the public health benefits that are associated with being in nature. Victorian Government departments and agencies are now developing a joint work programme that aligns with the Memorandum. This cross-government collaboration gives a mandate for strengthening partnerships across the health and environment sectors. It has also resulted in increased recognition of the contributions of nature to health, well-being and quality of life. This will ultimately lead to better public health outcomes and better environmental outcomes.

Protected areas, urban parks and other green and blue spaces not only benefit health and biodiversity but can often achieve significant cost savings in delivering health-care. For example, an evaluation of the largest 85 cities in the USA, covering a population of 57.2 million, identified an estimated $\$ 3.08$ billion of cost savings in health-care due to the health benefits of parks (Healthy Parks Healthy People 2017). Similarly, Parks Victoria, Australia, has estimated that Victoria's parks may save up to $\$ 200$ million annually in avoided health-care costs through physical activity in nature (Parks Victoria 2015). The cost savings for health-care also extend to mental 


\section{Box 16.4: Conservation and Health Benefits of Rouge National Urban Park, Canada}

Protected areas in and near urban areas can have significant benefits for biodiversity conservation and human health and well-being. Canada's first national urban park - Rouge National Urban Park - was created in the Greater Toronto Area in 2015, thanks to the efforts of Parks Canada, and a diverse partnership of countless individuals, indigenous partners, other levels of government, the park's farming community, community organisations, conservation groups and volunteers.

Once fully established, Rouge National Urban Park will be one of the largest and best protected urban parks globally, spanning $79.1 \mathrm{~km}^{2}$ in the heart of Canada's largest and most diverse metropolitan area and overlapping five municipalities. The location of this park, which is within easy access for $20 \%$ of the country's population, creates an excellent opportunity to engage current and future generations of Canadians with the natural, cultural and agricultural heritage of the area.

Parks Canada is collaborating with various community partners to develop and deliver initiatives for Rouge National Urban Park visitors and Greater Toronto Area residents. One programme is specifically focussed on the health benefits of the park. The Mood Walks programme, which is run by the Canadian Mental Health Association in partnership with Hike Ontario and Conservation Ontario builds on the fact that time in nature with others can improve symptoms of existing disorders by reducing anxiety or depression (e.g. Bratman et al. 2015). Guided walks are targeted at youth aged 13-24 years who are enrolled in the Child and Adolescent Mental Health Program at the Scarborough and Rouge Hospital. The walking activities aim to help these young people improve their physical and mental health as well as their social skills by developing outdoors and conservation interests, meeting fun and interesting people, and learning more about wildlife, forests, wetlands and farms.

Source: Rouge National Urban Park 2016.

health - a recent natural capital accounting for London found that the city's green spaces provide an estimated saving of $£ 370$ million annually for mental health-care and an additional $£ 580$ million from improved physical health (Vivid Economics Ltd 2017). More research is still needed, particularly on health benefits from nature for different demographic and social groups (Shanahan et al. 2015) to maximise understanding of the socio-economic benefits of protected areas, but there are now strong arguments that biodiversity conservation can be a key contributor to addressing both climate change adaptation and health-care (see Kabisch Chap. 5, this volume, and Cook et al. Chap. 11, this volume, for more detail). 


\subsection{Working Together to Promote Biodiversity Conservation and Health}

The 2030 Agenda for Sustainable Development and the SDGs will be the driving force behind much of the global work on sustainable development and conservation for the next decade (WCPA 2017). Biodiversity conservation, protected areas and conservation of natural ecosystems are directly relevant to many of the goals of the 2030 Agenda: to ensure healthy lives and promote well-being for all at all ages (SDG 3), water (SDG6), sustainable cities (SDG11), climate change adaptation (SDG 13) and biodiversity (SDGs 14 and 15) (WCPA 2017).

It is becoming increasingly clear that it is essential to build new partnerships to accelerate transformational change that will contribute to the well-being of people and the planet. Initiatives such as \#NatureForAll, which is led by the IUCN's World Commission on Protected Areas and Commission on Education and Communication and the Salzburg Global Seminar's Parks for the Planet Forum (Salzburg Global Seminar 2015), are efforts to do just that. \#NatureForAll is engaging hundreds of partner organisations to scale up efforts to raise awareness of nature and its values and to facilitate opportunities for people from all walks of life to experience, connect with and benefit from nature. The aim of this initiative is not only to improve health and well-being outcomes but also to increase cross-sectoral support and action for nature conservation by promoting the relevance of biodiversity conservation to other sectors. The Parks for the Planet Forum is a collaborative platform for transformative leadership that brings thought leaders and change-makers from diverse disciplines together to find ways to put nature at the very heart of human health and well-being, security and prosperity across the planet. These processes are calling for greater collaboration among biodiversity and natural resource experts, medical scientists, health practitioners, urban and regional planners, educators, economists and others to recognise, quantify and maximise the many health and well-being benefits to society from parks and nature both inside and outside cities.

While the provision of nature-based solutions is traditionally in the realm of environmental organisations and planners, greater involvement of the health sector will be critical for maximising benefits for both health and nature. Integrating policy on biodiversity, health and urban planning to realise joint benefits requires data from all fields to be linked and communicated to policy makers, to be considered in impact assessments and economic valuation of decisions (WHO and UNEP 2008; WHO and CBD 2015). In Toronto, Canada, for example, the City Council increased investments in urban green space in the city, including an increase in tree canopy cover, after the Medical Officer of Health cited studies on the benefits this would provide for health and reduced pollution (Toronto Medical Officer of Health 2015). Elsewhere medical practitioners and parks agencies are promoting experiences of nature as part of overall health-care (see Box 16.5). 


\section{Box 16.5: Nature Is Good Medicine}

- Dr. Robert Zarr, a paediatrician at Unity Health Care's Upper Cardozo Health Center in Washington DC, prescribes physical activity in parks to treat obesity, diabetes and mental health disorders (Washington Post 2015). His park prescription programme is based on the multiple medical benefits of spending time outdoors. Dr. Zarr is at the forefront of a movement among physicians who are making nature a fundamental part of their patients' health-care. They are now joined by the US National Park Service and the US Public Health Service.

- The British Trust for Conservation Volunteers has been promoting Green Gyms, which combine conservation volunteering with physical activity through planting trees. Doctors in the UK can refer people to Green Gyms to treat problems caused by mental health disorders, social isolation and physical inactivity (Trust for Conservation Volunteers 2016).

- Elders back on Country - The health and well-being benefits for Aboriginal people in Australia of being on 'Country' have been well documented. Two new projects were recently initiated in the State of Victoria to enable disabled Aboriginal Elders to get Back on Country by using Trail Rider wheelchairs. Parks Victoria was awarded both a Victorian Tourism Award and the Australian Tourism Award for its disability access programme.

\subsection{Looking Forward}

These examples highlight the need to work together and strengthen knowledge on the health benefits of parks and nature - across government, medical professions and the community to ensure a healthy environment to support a healthy society. This starts with dialogue, policy and action plans and the integration of biodiversity and natural ecosystems in urban and regional planning and development, addressing this at the level of neighbourhoods, cities and the wider landscape.

The SDGs present an important framework for collaborative action to respond to a range of global challenges and are premised on the notion that problems cannot be solved in isolation. To achieve the multiple goals of the SDGs, it will be important to protect, manage and restore key natural ecosystems, including protected and conserved areas, to improve natural resource management and to safeguard the ecosystem services and biodiversity that contribute to human well-being. The protection and effective management of natural ecosystems within and beyond city boundaries is critical to ensuring that urban environments are buffered from the effects of climate change and that vital services such as clean air, clean water and opportunities for outdoor recreation that are essential to human health and well-being can continue to be provided to an increasingly urban population. At the same time, rapid 
urbanisation will continue to put pressure on protected areas and other natural ecosystems. Conservation experts, municipal governments, city planners, health professionals and others will increasingly need to work together to ensure that urban planning and development proceeds in a way that ensures the ongoing protection of these critical natural systems and equitable access to natural spaces for all sectors of society.

There are many good arguments for extending and strengthening the management of protected areas and other natural areas (Stolton and Dudley 2010), but the clear links between healthy ecosystems and healthy people seem especially relevant at a time when societies are looking for new solutions to cope with climate change. The emphasis on biodiversity conservation, protected areas and natural landscapes as nature-based solutions for human health and climate change adaptation is now supported by a range of international policies and agreements. Investments in protected areas and other nature-based solutions offer cost-effective solutions that provide direct benefits for human welfare, public health and education, and build resilience to climate and environmental change. Achieving these multiple benefits will require new partnerships across different sectors but will become increasingly necessary in a world of changing climate and increasing urbanisation.

\section{References}

Ahn K (2017) The worldwide trend of using botanical drugs and strategies for developing global drugs. BMB Rep 50(3):111-116

Alcock I, White M, Cherrie M et al (2017) Land cover and air pollution are associated with asthma hospitalisations: a cross-sectional study. Environ Int 109:29-41

Armson D, Stringer P, Ennos AR (2013) The effect of street trees and amenity grass on urban surface water runoff in Manchester, UK. Urban For Urban Green 12(3):282-286

Beatley T (2014) Blue urbanism: exploring connections between cities and oceans. Island Press, Washington, DC

Bratman N, Hamilton JP, Hahn KS et al (2015) Nature experience reduces rumination and subgenual prefrontal cortex activation. PNAS 112(28):8567-8572

Convention on Biological Diversity (CBD) COP13 (2016) Cancun declaration on mainstreaming the conservation and sustainable use of biodiversity for well-being. https://www.cbd.int/cop/ cop-13/hls/cancun\%20declaration-en.pdf. Accessed 30 May 2018

Costanza R, d'Arge R, de Groot R et al (1997) The value of the world's ecosystem services and natural capital. Nature 387:253-260

Costanza R, Mageau M, Aquatic Ecology (1999) What is a healthy ecosystem. Aquat Ecol 33:105-115

Costanza R, Pérez-Maqueo O, Martinez ML et al (2008) The value of coastal wetlands to hurricane prevention. Ambio 37:241-248

D’Ambrosio L, Hennessy J (2017) Victorian Memorandum for health and nature. https://www. environment.vic.gov.au/biodiversity/victorian-memorandum-for-health-and-nature. Accessed 30 May 2018

Dudley N, Stolton S (2003) Running pure: the importance of forest protected areas to drinking water. WWF/Gland/World Bank, Washington, DC

Dudley N, Stolton S, Belokurov A et al (eds) (2010) Natural solutions: protected areas helping people cope with climate change. IUCN/World Bank/WWF, Gland 
East Dunbartonshire Council (2015) East dunbartonshire open space strategy 2015-2020

Gelsthorpe J (2017) Disconnect from nature and its effect on health and Well-being: a public engagement literature review. Natural History Museum, London

Gómez-Baggethun E, Gren A, Barton DN (2013) Urban ecosystem services. In: Elmqvist T, Fragkias M, Goodness J et al (eds) Urbanization, biodiversity and ecosystem services: challenges and opportunities. A global assessment. Springer, Dordrecht

Halpern BS (2003) The impact of marine reserves: do reserves work and does reserve size matter? Ecol Appl 13:117-137

Hartig T, Mitchell R, de Vries S et al (2014) Nature and health. Annu Rev Public Health 35:207-228

Healthy Parks Healthy People (2017) Urban planning and the importance of green space in cities to human and environmental health. http://www.hphpcentral.com/article/urban-planning-andthe-importance-of-green-space-in-cities-to-human-and-environmental-health. Accessed 31 May 2018

HM Government (2018) A green future: Our 25-year plan to improve the environment. https:// www.gov.uk/government/uploads/system/uploads/attachment_data/file/693158/25-year-environment-plan.pdf. Accessed 31 May 2018

International Federation of Red Cross and Red Crescent Societies (IFRC) (2002) Mangrove planting saves lives and money in Vietnam. World disasters report focus on reducing risk. IFRC, Geneva

International Union for the Conservation of Nature (2014) Urban protected areas: profiles and best practice guidelines. IUCN, Gland

International Union for the Conservation of Nature (2016a) World conservation congress resolution Res-064-EN, to strengthen cross-sector partnerships to recognise the contributions of nature to health, well-being and quality of life. https://www.iucn.org/sites/dev/files/content/ documents/wcc_2016_res_064_en.pdf. Accessed 31 May 2018

International Union for the Conservation of Nature (2016b) Nature-based solutions to address global societal challenges. IUCN, Gland

International Union for the Conservation of Nature, Canadian Parks Council (2017) The \#NatureForAll Playbook. An action guide for inspiring love of nature. https://natureforall. global/s/NatureForAll-Playbook-ENG.pdf. Accessed 31 May 2018

Louv R (2005) Last child in the woods: saving our children from nature-deficit disorder. Algonquin Books, Chapel Hill

Marselle MR, Irvine KN, Warber SL (2014) Examining group walks in nature and multiple aspects of well-being: a large scale study. Ecopsychology 6:134-147. https://doi.org/10.1089/ eco.2014.0027

Mcdonald RI, Kareiva P, Forman RTT (2008) The implications of current and future urbanization for global protected areas and biodiversity conservation. Biol Conserv 141:1695-1703

Parks Victoria (2015) Valuing Victoria's Parks. http://parkweb.vic.gov.au/_data/assets/pdf_ file/0008/666350/Valuing-Victorias-parks.pdf. Accessed 30 May 2018

Richardson EA, Pearce J, Mitchell R et al (2013) Role of physical activity in the relationship between urban green space and health. Public Health 127(4):318-324

Russell R, Guerry AD, Balvanera P et al (2013) Humans and nature: how knowing and experiencing nature affect well-being. Annu Rev Environ Resour 38:473-502

Salzburg Global Seminar (2015) Parks for the planet forum, nature, health and a new urban generation. http://www.salzburgglobal.org/topics/article/parks-for-the-planet-forum-nature-healthand-a-new-urban-generation-report-now-online.html. Accessed 31 May 2018

Sandifer PA, Sutton-Grier AE, Ward BP (2015) Exploring connections among nature, biodiversity, ecosystem services, and human health and Well-being: opportunities to enhance health and biodiversity conservation. Ecosyst Serv 12:1-15

Shanahan DF, Lin BB, Bush R et al (2015) Toward improved public health outcomes from urban nature. Am J Public Health 105(3):470-477

State of Victoria Department of Environment, Land, Water and Planning (2017) Protecting Victoria's environment - biodiversity 2037. https://www.environment.vic.gov.au/biodiversity/ biodiversity-plan. Accessed 31 May 2018 
Stolton S, Dudley N (2010) Arguments for protected areas: multiple benefits for conservation and use. Earthscan, London

Stolton S, Dudley N, Randall J (2008) Natural security: protected areas and hazard mitigation. WWF, Gland

Teisl MF, O'Brien K (2003) Who cares and who acts? Outdoor recreationists exhibit different levels of environmentalism. Environ Behav 35(4):506-522

Toronto Medical Officer of Health (2015) Green city: why nature matters to health, Report for Toronto Board of Health. Toronto Public Health, Toronto

Townsend M, Henderson-Wilson C, Warner E et al (2015) Healthy parks healthy people: the state of the evidence. Parks Victoria, Melbourne

Trust for Conservation Volunteers (TCV) (2016) Green gym evaluation report 2016. https://www. tcv.org.uk/sites/default/files/green-gym-evaluation-report-2016.pdf. Accessed 31 May 2018

United Nations (2014) World urbanisation prospects, 2014 revision. https://esa.un.org/unpd/wup. Accessed 31 May 2018

United Nations (2015) Paris agreement. https://unfccc.int/process-and-meetings/the-paris-agreement/the-paris-agreement. Accessed 31 May 2018

United Nations (2016) Draft outcome document of the United Nations conference on housing and sustainable urban development (Habitat III). New Urban Agenda. http://habitat3.org/the-newurban-agenda. Accessed 31 May 2018

Vivid Economics Ltd (2017) Natural capital accounts for public green space in London. Report prepared for Greater London Authority, National Trust and Heritage Lottery Fund. https:// www.london.gov.uk/what-we-do/environment/parks-green-spaces-and-biodiversity/greeninfrastructure/natural-capital?source=vanityurl. Accessed 31 May 2018

Washington Post (2015) D.C. doctor's Rx: a stroll in the park instead of a trip to the pharmacy. https://www.washingtonpost.com/national/health-science/why-one-dc-doctor-is-prescribingwalks-in-the-park-instead-of-pills/2015/05/28/03a54004-fb45-11e4-9ef4-1bb7ce3b3fb7_ story.html?utm_term $=.41 \mathrm{bc} 02788294$. Accessed 31 May 2018

Watson J, Dudley N, Segan DB et al (2014) The performance and potential of protected areas. Nature 515:67-73

World Bank (2010) Convenient solutions to an inconvenient truth: ecosystem-based approaches to climate change. World Bank, Washington, DC

World Commission on Protected Areas (WCPA) (2011) Natural solutions: protected areas helping people to cope with climate change. https://portals.iucn.org/library/sites/library/files/documents/Rep-2011-021.pdf. Accessed 31 May 2018

World Commission on Protected Areas (WCPA) (2012) Natural solutions: protected areas maintaining essential water supplies. https://www.iucn.org/sites/dev/files/import/downloads/natsols_water_flyer_final.pdf. Accessed 31 May 2018

World Commission on Protected Areas (WCPA) (2015) Natural solutions: protected areas are vital for human health and well-being. https://www.iucn.org/sites/dev/files/import/downloads/natural_solutions_pas_health_and_well_being.pdf. Accessed 31 May 2018

World Commission on Protected Areas (WCPA) (2017) Natural solutions: protected areas helping to meet the sustainable development goals. https://www.iucn.org/sites/dev/files/natural_solutions_-_sdgs_final_2.pdf. Accessed 31 May 2018

World Health Organisation (2005) Preventing chronic diseases: a vital investment. World Health Organisation, Geneva

World Health Organisation (2014) Global status report on non-communicable diseases. World Health Organisation, Geneva

World Health Organisation and Secretariat of the Convention on Biological Diversity (2015) Connecting global priorities: biodiversity and human health. A state of knowledge review. World Health Organisation/Secretariat of the Convention on Biological Diversity, Geneva

World Health Organisation (WHO) 2016 Ambient air pollution: A global assessment of exposure and burden of disease. World Health Organisation, Geneva. 
World Health Organisation and United Nations Environment Programme (2008) Health and environment: managing the linkages for sustainable development. A toolkit for decision makers. World Health Organisation, Geneva

Wright P, Matthews C (2014) Building a culture of conservation: state-of-knowledge report on connecting people to nature in parks. http://cpaws.org/uploads/buildingacultureofconservation-web.pdf. Accessed 31 May 2018

Open Access This chapter is licensed under the terms of the Creative Commons Attribution 4.0 International License (http://creativecommons.org/licenses/by/4.0/), which permits use, sharing, adaptation, distribution and reproduction in any medium or format, as long as you give appropriate credit to the original author(s) and the source, provide a link to the Creative Commons license and indicate if changes were made.

The images or other third party material in this chapter are included in the chapter's Creative Commons license, unless indicated otherwise in a credit line to the material. If material is not included in the chapter's Creative Commons license and your intended use is not permitted by statutory regulation or exceeds the permitted use, you will need to obtain permission directly from the copyright holder.

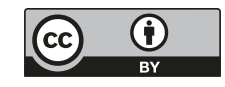

